\title{
Pengaruh Harga dan Kualitas Produk Terhadap Keputusan Pembelian Fried Chicken di Rocket Chicken Bandar Kota Kediri
}

\section{The Effect of Price and Product Quality on Purchasing Decisions of Fried Chicken in Rocket Chicken Bandar Kediri City}

\author{
Dhea Febriana Elmiliasari \\ Prodi Ekonomi Syariah IAIN Kediri \\ elmiliasaridhea@gmail.com
}

\begin{abstract}
Food and beverage business growth is still recorded as a business that has high growth in various parts of the world. Many outlets have sprung up offering food and beverage products in various forms. This is because food is one of the basic needs that must be met by everyone. One of them is the Rocket Chicken fast food restaurant. Giving a good price and quality of the product to the buyer will influence the buyer in making a purchase decision. If the price and quality of the product received are as expected, then the price and quality of the product are perceived as good and satisfying. Buyers who are satisfied with the price and quality of the product will then repurchase a product. This research is a quantitative study, the instrument in this study is a questionnaire given to respondents in the study. The population in this study were consumers of fried chicken in Rocket Chicken. The sampling technique used in this study is probability sampling. The number of samples in this study were 100 people. The results of this study found that the regression equation formed was $Y=7.156+0.262 X 1+0.616 X 2$. The results of this study partially indicate that the price is quite influential on the purchase decision for fried chicken of 0.431 or $43.1 \%$. And product quality has a positive effect on purchasing decisions fried chicken of 0.760 or 76.0\%. Simultaneously the price and quality of the product significantly influence the purchasing decision of fried chicken by 0.665 or $66.5 \%$ while $33.5 \%$ is influenced by other factors not included in this study such as location and promotion which also plays an important role in purchasing decisions other than price and product quality.
\end{abstract}

Keywords: Price, Product Quality, Purchase Decision. 


\begin{abstract}
Abstrak
Pertumbuhan bisnis makanan dan minuman masih tercatat sebagai bisnis yang mengalami pertumbuhan tinggi di berbagai belahan dunia. Banyak bermunculan outlet yang menawarkan produk makanan dan minuman dalam berbagai bentuk. Hal ini disebabkan makanan merupakan salah satu kebutuhan pokok yang harus dipenuhi semua orang. Salah satunya restoran cepat saji Rocket Chicken. Pemberian harga dan kualitas produk yang baik pada pembeli akan mempengaruhi pembeli dalam melakukan keputusan pembelian. Apabila harga dan kualitas produk yang diterima sesuai dengan yang diharapkan, maka harga dan kualitas produk dipersepsikan baik dan memuaskan. Pembeli yang merasa puas akan harga dan kualitas produk maka akan melakukan pembelian ulang terhadap suatu produk. Penelitian ini merupakan penelitian kuantitatif, instrumen dalam penelitian ini berupa angket yang diberikan kepada responden dalam penelitian. Populasi dalam penelitian ini adalah konsumen fried chicken di Rocket Chicken. Teknik pengambilan sampel yang digunakan dalam penelitian ini adalah probability sampling. Jumlah sampel dalam penelitian ini adalah 100 orang. Hasil penelitian ini mendapatkan bahwa persamaan regresi yang terbentuk adalah $\mathrm{Y}=$ $7,156+0,262 X_{1}+0,616 X_{2}$. Hasil penelitian ini secara parsial menunjukkan bahwa harga cukup berpengaruh terhadap keputusan pembelian fried chicken sebesar 0,431 atau 43,1\%. Dan kualitas produk berpengaruh positif terhadap keputusan pembelian fried chicken sebesar 0,760 atau 76,0\%. Secara simultan harga dan kualitas produk berpengaruh signifikan terhadap keputusan pembelian fried chicken sebesar 0,665 atau 66,5\% sedangkan 33,5\% dipengaruhi oleh faktor lain yang tidak dimasukan dalam penelitian ini seperti lokasi dan promosi yang juga memegang peranan penting dalam keputusan pembelian selain harga dan kualitas produk .
\end{abstract}

Kata Kunci: Harga, Kualitas Produk, Keputusan Pembelian.

\title{
Pendahuluan
}

Pertumbuhan bisnis makanan dan minuman masih tercatat sebagai bisnis yang mengalami pertumbuhan tinggi di berbagai belahan dunia. Banyak bermunculan outlet yang menawarkan produk makanan dan minuman dalam berbagai bentuk. Hal ini disebabkan makanan merupakan salah satu kebutuhan 


\section{Dhea Febriana| Pengaruh Harga dan Kualitas...}

pokok yang harus dipenuhi semua orang. Pesatnya pertumbuhan industri jasa makanan memicu munculnya restoran cepat saji. ${ }^{1}$

Menjamurnya restoran cepat saji membuat masyarakat mudah menikmati makanan yang disajikan secara cepat. Terkait dengan kebutuhan primer manusia jenis usaha tempat makan menjadi salah satu bisnis yang menjanjikan. Budaya makan diluar rumah, tingkat konsumeris yang tinggi dan jadwal kerja manusia yang padat membuat masyarakat lebih memilih untuk makan di restoran. Melihat besarnya peluang ini, para pengusaha termotivasi untuk memulai bisnis restoran yang menjual makanan dan minuman yang disesuaikan dengan kebutuhan mayoritas masyarakat. Industri pangan bukan lagi hanya dibutuhkan untuk memenuhi kebutuhan biologis namun juga menjadi sarana hiburan dan gaya hidup baru dikalangan masyarakat. Bisnis kuliner dimassa kini harus mementingkan cita rasa dan melihat kebutuhan konsumen.

Seiring dengan perkembangan tersebut, semakin banyak para pelaku usaha mendirikan usaha kuliner dalam berbagai bentuk mulai dari pedagang kaki lima, warung rumah makan, hingga restoran waralaba (franchise). Banyaknya restoran franchise dengan konsep fast food yang berdiri di Kota Kediri membuat para pelaku usaha bersaing dengan restoran yang lainnya. Persaingan tersebut menuntut para pelaku bisnis untuk mampu memaksimalkan kinerjanya agar dapat memenangkan persaingan bisnis.

Perencanaan sebuah usaha restoran dibutuhkan ketelitian dan perencanaan yang panjang serta matang. Sebuah restoran tidak hanya menjual produk tetapi juga menjual jasa. Produk berupa makanan yang bisa pelanggan nikmati karena berbentuk fisik dan jasa yang diberikan oleh karyawan restoran

\footnotetext{
${ }^{1}$ Vina mandasari (2011), Analisis Kepuasan Konsumen Terhadap Restoran Cepat Saji Melalui Pendekatan Data Mining : Studi Kasus xyz. Jurnal generic vol 6 no 1.
} 
kepada pelanggan (tangible and intangible). Pertumbuhan usaha restoran yang semakin beragam dan bervariasi tentu membuat para pengusaha restoran harus dapat bersaing demi kelangsungan usahanya.

Dalam kondisi persaingan bisnis yang ketat, hal yang menjadi prioritas utama sebuah restoran adalah minat konsumen untuk membeli produknya. Pelanggan yang merasa tertarik dengan produknya kemungkinan besar akan terus datang dan membeli kembali ke restoran tersebut dan berdampak pada pemasukan serta laba dari restoran tersebut. Sedangkan pelanggan yang merasa tidak minat dengan produk yang ditawarkan mayoritas akan beralih ke restoran lain, mengingat banyaknya usaha bisnis restoran di masa kini.

Menurut Boyd Walker pengambilan keputusan merupakan sebuah pendekatan penyelesaian masalah pada kegiatan manusia membeli suatu produk guna memenuhi keinginan dan kebutuhan. ${ }^{2}$ Perilaku konsumen menjadi hal-hal yang mendasari konsumen untuk membuat keputusan pembelian. Adapun hal-hal tersebut adalah proses dan aktivitas ketika seseorang (konsumen) berhubungan dengan pencarian, pemilihan, pembelian, penggunaan, serta pengevaluasian produk dan jasa. Menurut Kotler dan Keller, sebelum konsumen melakukan pembelian, ada beberapa tahap yang harus dilalui. Tahap-tahapan dalam proses pengambilan keputusan yaitu pengenalan masalah, pencarian informasi, evaluasi alternative, keputusan pembelian, dan perilaku pasca pembelian.

Proses pertama adalah pengenalan masalah, dimana konsumen merasa adanya ingin memiliki atau membeli sesuatu untuk memenuhi kebutuhannya. Berikutnya konsumen akan berusaha mencari dan mengumpulkan informasi tentang barang yang diinginkan. Setelah mendapatkan informasi yang cukup,

\footnotetext{
${ }^{2}$ Boyd I Walker, Manajemen Pemasaran, Jilid I, Ahli Bahasa Oleh Imam Nurmawan, Jakarta:Erlangga, 1997, Hal 123
} 


\section{Dhea Febriana| Pengaruh Harga dan Kualitas...}

konsumen mulai membandingkan dengan produk serupa lainnya untuk memperoleh alternatif produk, ini disebut sebagai evaluasi alternatif. Dalam evaluasi alternatif ini konsumen akan membuat keputusan apakah akan membeli atau tidak. Apabila konsumen membuat keputusan untuk membeli maka akan berada dalam tahap terakhir yaitu perilaku pasca pembelian. Perilaku pasca pembelian, konsumen akan merasakan manfaat dari produk dan juga akan mempengaruhi konsumen untuk melakukan pembelian ulang atau tidak. $^{3}$

Menurut Rambat Lupiyoadi, bauran pemasaran merupakan seperangkat / alat bagi pemasar yang terdiri atas berbagai unsur suatu program pemasaran yang perlu dipertimbangkan agar implementasi strategi pemasaran dan penentuan posisi yang ditetapkan dapat berjalan sukses. Menurut Kotler, bahwa bauran pemasaran (marketing mix) adalah seperangkat alat pemasaran yang digunakan perusahaan untuk terus-menerus mencapai tujuan di pasar sasarannya. Para pemasar umumnya menggunakan bauran pemasaran ini sebagai alat untuk mendapat tanggapan yang diinginkan oleh perusahaan dari pasaran mereka atas produk yang ditawarkan oleh perusahaan.

Harga merupakan sesuatu yang diserahkan dalam pertukaran untuk mendapatkan suatu barang maupun jasa. Harga khususnya merupakan pertukaran uang dengan barang atau jasa. Juga pengorbanan waktu karena menunggu untuk memperoleh barang atau jasa. Harga merupakan salah satu faktor penentu ketika pembeli akan menentukan suatu keputusan pembelian terhadap suatu produk atau jasa. Apalagi produk atau jasa tersebut merupakan

\footnotetext{
${ }^{3}$ Aditya Hangga Supangat (2017), Pengaruh Citra Merek, Kualitas Produk, Harga Terhadap Keputusan Pembelian, Jurnal Ilmu Dan Riset Manajemen, Vol 6 No 9.
} 
kebutuhan pokok sehari-hari seperti makanan, minuman dan kebutuhan pokok lainnya, pembeli akan sangat memperhatikan harganya. ${ }^{4}$

Produk merupakan segala sesuatu yang dapat ditawarkan produsen untuk diperhatikan, diminta, dicari, dibeli, digunakan, atau dikonsumsi pasar sebagai pemenuhan kebutuhan atau keinginan pasar yang bersangkutan. Menurut Kotler dan Amstrong produk adalah apa saja yang dapat ditawarkan produsen untuk diperhatikan, dimiliki, dipergunakan, atau dikonsumsi. Produk tersebut dapat memuaskan keinginan atau kebutuhan konsumen. ${ }^{5}$ Menurut Kotler dan Amstrong, kualitas produk adalah kemampuan suatu barang untuk memberikan hasil kinerja yang sesuai atau melebihi dari apa yang diinginkan oleh pelanggan. ${ }^{6}$. Kita dapat mengatakan bahwa penjual telah menghasilkan mutu bila produk atau pelayanan penjual tersebut memenuhi atau melebihi harapan pelanggan. Terdapat kecenderungan bagi konsumen untuk memilih produk makanan yang berkualitas, sesuai dengan selera dan keinginan serta memiliki harga yang relatif terjangkau. ${ }^{7}$

Pada saat ini kuliner sedang menjadi suatu kebutuhan masyarakat yang mempunyai bermacam-macam menu makanan salah satunya fried chicken. Fried chicken akhir-akhir ini mengalami peningkatan pembelian. Kreativitas penjual untuk membuat varian dari rasa saos dan sambal yang membuat konsumen tertarik.

${ }^{4}$ Fifyanita Ghanimata dan Mustafa Kamal (2012), Analisis Pengaruh Harga, Kualitas Produk, Dan Lokasi Terhadap Keputusan Pembelian, Diponegoro Journal Of Management Vol I No 2.

${ }^{5}$ Cholifatun Nisak, Pengaruh Harga, Keberagaman Model Produk, Kualitas Informasi Dan Kepercayaan Terhadap Keputusan Pembelian Online Pada Toko Tas Online Sabila Store, Jurnal Universitas Diponegoro.

${ }^{6}$ Philip Kotler dan Amstrong Gary, Prinsip-Prinsip Pemasaran, Terj Imam Nurmawan, (Jakarta Erlangga, 2001), 346

${ }^{7}$ Fifyanita Ghanimata dan Mustafa Kamal (2012), Analisis Pengaruh Harga, Kualitas Produk, Dan Lokasi Terhadap Keputusan Pembelian, Diponegoro Journal Of Management Vol I No 2. 


\section{Dhea Febriana| Pengaruh Harga dan Kualitas...}

Rocket Chicken berdiri pada 21 Februari 2010, sesuai perkembangan dan mulai di-franchise-kan dengan pola kemitraan hal ini dapat mendorong pengusaha-pengusaha baru dengan modal yang terjangkau. Melalui tahapan proses yang panjang, akhirnya berdirilah gerai-gerai Fast Food Restaurant dengan brand Rocket Chicken mulai dari daerah tingkat 1 hingga daerah tingkat 2 seperti di DIY, Jawa Tengah, Jawa Timur dan Jawa Barat. Keunggulan Rocket Chicken dengan membidik pangsa pasar seluruh kalangan lapisan masyarakat sehingga bisa didirikan hingga ke daerah-daerah. Rocket Chicken sebagai usaha yang mempunyai Brandawareness tinggi, prospektif dan marketable. ${ }^{8}$

\section{Metode}

Metode penelitian yang digunakan dalam penelitian ini adalah metode penelitian kuantitatif. Sedangkan jenis penelitian ini merupakan penelitian kausalitas. Penelitian kausalitas yaitu penelitian hubungan yang bersifat sebab akibat

\section{Pembahasan}

Konsumen dalam melakukan keputusan pembelian selalu mempertimbangkan hal yang berhubungan dengan kualitas dari produk yang akan dibeli. Kualitas produk dapat diartikan kemampuan dari produk untuk menjalankan fungsinya yang mencakup daya tahan, kehandalan atau kemajuan, kekuatan, kemudahan dalam pengemasan dan reparasi produk dan ciri-ciri lainnya. Persepsi konsumen terhadap kualitas produk akan membentuk preferensi dan sikap yang pada gilirannya akan mempengaruhi keputusan untuk membeli atau tidak.

\footnotetext{
${ }^{8} \mathrm{http} / / /$ rocketchickenindonesia.com/ diakses pada tanggal 10 september 2018
} 
Pada saat konsumen akan mengambil suatu keputusan pembelian, variabel produk merupakan pertimbangan paling utama, karena produk adalah tujuan utama bagi konsumen untuk memenuhi kebutuhannya. Konsumen yang merasa cocok dengan suatu produk dan produk tersebut dapat memenuhi kebutuhannya, maka konsumen akan mengambil keputusan untuk membeli produk tersebut. Hal ini diperkuat dengan hasil penelitian Ghanimata. yang menyatakan bahwa variabel kualitas produk berpengaruh positif terhadap keputusan pembelian.

Faktor lain yang mempengaruhi keputusan pembelian adalah harga. Harga dapat menjadi indikator kualitas produk. Konsumen biasanya mengidentikkan harga produk yang mahal dengan kualitas yang baik dan apabila harga produk murah, maka konsumen meragukan kualitasnya. Ketika seseorang berbelanja, hal awal yang sering diperhatikan adalah harga, disusul dengan beberapa faktor lain. Tingginya harga yang ditawarkan harus sesuai dengan manfaat yang akan diterima oleh konsumen yang mengkonsumsinya. Harga yang terlalu tinggi atau terlalu rendah akan mempengaruhi keputusan pembelian konsumen. Harga yang terlalu tinggi akan membuat konsumen beralih ke produk lain yang sejenis tetapi dengan harga yang lebih murah, begitu sebaliknya, jika harga yang ditawarkan terlalu rendah maka konsumen akan ragu dengan kualitas produk yang ditawarkan sehingga menunda keputusan untuk membeli produk tersebut.

\section{A. Harga Fried Chicken pada Rocket Chicken Bandar Kota Kediri}

Menurut Philip Kotler harga (price) dalam arti sempit adalah jumlah yang ditagihkan atas suatu produk atau jasa. Lebih luas lagi, harga adalah jumlah semua nilai yang diberikan oleh pelanggan untuk mendapatkan 


\section{Dhea Febriana| Pengaruh Harga dan Kualitas...}

keuntungan dengan memiliki atau menggunakan suatu produk atau jasa. ${ }^{9}$ Harga adalah salah satu elemen dalam bauran pemasaran yang menghasilkan pendapatan. Harga memiliki indikator sebagai berikut :

1. Keterjangkauan harga

Konsumen bisa menjangkau harga yang telah ditetapkan oleh perusahaan atau pedagang. Produk biasanya ada beberapa jenis dalam satu merek dan harganya juga berbeda dari yang termurah sampai termahal. Dengan harga yang ditetapkan oleh Rocket Chicken para konsumen banyak yang membeli produk fried chicken. Dari 100 responden sebanyak $76 \%$ menyatakan setuju bahwa fried chicken di Rocket Chicken mempunyai harga yang murah.

2. Kesesuaian Harga dengan Kualitas Produk

Kesesuaian harga dengan kualitas produk merupakan perbandingan antara harga yang ada pada barang yang dijual sesuai dengan kualitas barang yang akan dibeli oleh konsumen. Dalam hal ini fried chicken memenuhi kesesuaian antara harga dan kualitas. Dari 100 responden sebanyak $62 \%$ menyatakan setuju bahwa fried chicken di Rocket Chicken mempunyai harga yang sesuai dengan kualitas produk yang diinginkan konsumen.

3. Daya Saing Harga

Konsumen sering membandingkan harga suatu produk dengan produk lainnya. Dalam hal ini mahal dan murahnya suatu produk sangat dipertimbangkan oleh konsumen pada saat akan membeli suatu produk. Dalam hal ini Rocket Chicken mempunyai harga yang lebih murah daripada pesaingnya. Dari 100 responden sebanyak 68\%

9 Philip Kotler, Gary Amstrong, Prisip - Prinsip Pemasaran, Edisi Ke-12, (Jakarta:Erlangga,2008),345 
menyatakan setuju bahwa harga fried chicken di Rocket Chicken mempunyai harga yang lebih murah daripada tempat fast food lainnya.

4. Kesesuaian harga dengan manfaat.

Konsumen memutuskan untuk membeli suatu produk jika manfaat yang dirasakan lebih besar atau sama dengan yang telah dikeluarkan untuk mendapatkannya. Jika konsumen merasakan manfaat produk lebih kecil dari uang yang dikeluarkan maka konsumen akan beranggapan bahwa produk tersebut mahal dan konsumen akan berfikir dua kali untuk melakukan pembelian ulang. Dari 100 responden sebanyak 69\% setuju menyatakan bahwa harga fried chicken di Rocket Chicken mempunyai harga yang sesuai dengan manfaat yang didapat. Dengan harga yang murah mendapatkan porsi makan yang pas.

Dari hasil penelitian kepada 100 responden Rocket Chicken Bandar Kota Kediri dengan menggunakan indikator penelitian seperti diatas, pada bahwa sebanyak 14 responden menjawab sangat murah dengan frekuensi relatif 14\%, 72 responden menjawab murah dengan frekuensi relatif $86 \%$. Sehingga dapat disimpulkan bahwa harga fried chicken di Rocket Chicken Bandar Kota Kediri termasuk kategori murah.

\section{B. Kualitas Produk Fried Chicken pada Rocket Chicken Bandar Kota Kediri}

Menurut Kotler \& Amstrong kualitas produk adalah salah satu sarana positioning utama pemasar. Kualitas memiliki dampak langsung pada kinerja produk atau jasa. Oleh karena itu, kualitas berhubungan erat dengan nilai dan kepuasan pelanggan. Dalam arti yang lebih sempit, kualitas dapat didefinisikan sebagai "bebas dari kerusakan". Dari pernyataan tersebut, dapat disimpulkan bahwa kualitas suatu produk erat 


\section{Dhea Febriana| Pengaruh Harga dan Kualitas...}

dengan baik buruknya suatu produk. Kualitas suatu produk, menjadi salah satu pertimbangan konsumen dalam memilih produk yang akan dibeli. Oleh karena itu, perusahaan dituntut untuk bisa memproduksi barang atau jasa yang berkualitas, sehingga dapat bersaing dengan kompetitor. Jika kualitas produk sesuai harapan, maka konsumen akan membeli produk tersebut.

Menurut West, Wood dan Harger, Gaman dan Sherrington serta Jones dalam Margaretha dan Edwin terdapat sembilan indikator pada kualitas produk seperti berikut ini:

1. Penampilan

Salah satu faktor yang mempengaruhi kualitas makanan yaitu dari segi penampilan. Dalam penelitian ini, penampilan merupakan bagaimana fried chicken disajikan untuk dihidangkan kepada konsumen. Makanan yang disajikan harus baik dilihat saat berada di piring, dimana hal tersebut adalah suatu faktor yang penting. Dari 100 responden sebanyak $70 \%$ menyatakan setuju bahwa penampilan fried chicken di Rocket Chicken mempunyai penampilan yang menarik dan menggugah selera.

2. Porsi

Porsi makanan merupakan ukuran maupun takaran makanan yang dikonsumsi pada tiap kali makan. Suatu makanan disajikan dengan porsi yang berbeda-beda, ada yang disajikan dengan porsi yang banyak dan ada yang disajikan dengan porsi yang sedikit. Dari 100 responden sebanyak 73,5\% menyatakan setuju bahwa porsi fried chicken di Rocket Chicken mempunyai pilihan porsi yang bervariasi. 


\section{Tekstur}

ada banyak tekstur makanan antara lain halus atau tidak, cair atau padat, keras atau lembut, kering atau lembab. Dari 100 responden sebanyak $76 \%$ menyatakan setuju bahwa tekstur fried chicken di Rocket Chicken mempunyai tekstur yang renyah.

4. Aroma

Aroma adalah reaksi dari makanan yang akan mempengaruhi konsumen sebelum konsumen menikmati makanan, konsumen dapat mencium makanan tersebut. Dari 100 responden sebanyak $78 \%$ menyatakan setuju bahwa aroma fried chicken di Rocket Chicken mempunyai aroma yang menggugah selera.

5. Rasa

Rasa titik perasa dari lidah adalah kemampuan memdeteksi dasar yaitu manis, asam, pahit, asin, makanan tertentu empat rasa ini digabungkan sehingga menjadi satu rasa yang unik dan menarik untuk dinikmati. ${ }^{10}$ Dari 100 responden sebanyak $78 \%$ menyatakan setuju bahwa rasa fried chicken di Rocket Chicken mempunyai rasa yang enak.

Dari hasil penelitian kepada 100 responden Rocket Chicken Bandar Kota Kediri dengan menggunakan indikator penelitian seperti diatas, bahwa sebanyak 6 responden menjawab sangat baik dengan frekuensi relatif 6\%, 79 responden menjawab baik dengan frekuensi relatif $85 \%$. Sehingga dapat disimpulkan bahwa kualitas produk fried chicken di Rocket Chicken Bandar Kota Kediri termasuk kategori baik.

${ }^{10}$ Abd Karim Basir, Agus Achmad Suhendra, Sari Wulandari, “Analisis Kebutuhan Produk Keripik Kentang Usaha Kecil Menengah Cumelly Menggunakan Integrasi Food Quality Dan Model Kano", E-Proceeding Of Enggineering : Volume 2, Nomor 3 Issn : 23559365,(Desember 2015),7501-7502. 


\section{Dhea Febriana| Pengaruh Harga dan Kualitas...}

\section{Keputusan Pembelian Fried Chicken Pada Rocket Chicken Bandar}

\section{Kota Kediri}

Keputusan pembelian menurut Scniffman dan Kanuk adalah suatu keputusan seseorang dimana dia memilih salah satu dari beberapa alternative yang ada. Dengan adanya berbagai pilihan yang ditawarkan konsumen dapat mengambil keputusan yang terbaik dari yang ditawarkan. ${ }^{11}$ Sedangkan menurut Kotler menyatakan bahwa: "Keputusan pembelian adalah suatu proses penyelesaian masalah yang terdiri dari menganalisa kebutuhan dan keinginan, pencarian informasi, penilaian sumber-sumber seleksi terhadap alternatif pembelian, keputusan pembelian, dan perilaku setelah pembelian.”.

Penjelasan dari indikator keputusan pembelian diantaranya sebagai berikut :

\section{Identifikasi Masalah}

Proses membeli diawali ketika seseorang mendapatkan stimulus (pikiran,tindakan atau motivasi) yang mendorong dirinya untuk mempertimbangkan pembelian barang atau jasa tertentu. Dalam penelitian berdasarkan angket yang disebar pada responden, dari 100 responden sebanyak $87 \%$ konsumen membeli fried chicken untuk memenuhi kebutuhan dalam hal makanan yang akan dikonsumsi.

2. Pencarian Informasi

Setelah konsumen mengetahui kebutuhannya maka konsumen akan mencari tau tentang produk tersebut. Hal ini juga dilakukan oleh konsumen Rocket Chicken yang mendapat informasi dari orang yang sudah pernah membeli fried chicken. Selain itu Rocket Chicken juga

\footnotetext{
${ }^{11}$ Schiffman Leon dan Kanuk Leslie Lazar, Perilaku Konsumen Edisi 7, 26.
} 
memberi kemudahan informasi seperti melalui iklan, media sosial, dan spanduk. Dari 100 responden sebanyak 77,5\% menyatakan setuju bahwa mereka mendapatkan kemudahan dalam mencari informasi tentang Rocken Chicken.

\section{Evaluasi Alternatif}

Berdasarkan pencarian informasi yang telah diperoleh konsumen dari beberapa sumber, sebelum membeli konsumen dapat memilih untuk mengevaluasi terlebih dahulu. Dari 100 responden sebanyak $86 \%$ menyatakan setuju bahwa mereka melakukan penilaian terlebih dahulu sebelum memutuskan untuk membeli di Rocket Chicken.

4. Keputusan Pembelian

Setelah konsumen melakukan pengenalan kebutuhan dan pencarian informasi, tahap selanjutnya yaitu penentuansikap oleh konsumen apakah membeli atau tidak. Dari 100 responden sebanyak $82,5 \%$ menyatakan setelah melakukan penilaian responden merasa yakin untuk memutuskan membeli fried chicken di Rocket Chicken adalah ppilihan yang tepat.

5. Perilaku Pasca Pembelian

Perilaku pasca pembelian merupakan sikap konsumen setelah melakukan pembelian, apakah dari pembelian yang telah dilakukan konsumen merasa puas atau tidak. Apabila konsumen merasa puas kemungkinan konsumen akan melakukan pembelian ulang untuk pembelian yang selanjutnya. Dari 100 responden sebanyak 79\% menyatakan setuju bahwa konsumen akan melakukan pembelian ulang.

Dalam penelitian kepada 100 responden Rocket Chicken dengan menggunakan indikator keputusan pembelian, bahwa sebanyak 42 menjawab sangat tinggi dengan frekuensi relatif 42\%, 57 responden 
Dhea Febriana| Pengaruh Harga dan Kualitas...

menjawab tinggi dengan frekuensi relatif 99\%. Sehingga dapat disimpulkan bahwa keputusan pembelian di Rocket Chicken termasuk dalam kategori tinggi.

\section{Pengaruh Harga dan Kualitas Produk terhadap Keputusan} Keputusan Pembelian Fried Chicken di Rocket Chicken Bandar Kota Kediri.

Peneliti melakukan uji pada variabel harga $\left(\mathrm{X}_{1}\right)$ dan kualitas produk $\left(\mathrm{X}_{2}\right)$ berpengaruh secara signifikan secara simultan terhadap Keputusan Pembelian (Y) pada konsumen fried chicken di Rocket Chicken. Hal ini dapat diketahui pada perhitungan menggunakan SPSS 21 dengan uji korelasi pearson ganda memperoleh nilai signifikansi $\mathrm{F}$ change sebesar 0,001 < 0,05 maka variabel lokasi $\left(\mathrm{X}_{1}\right)$ dan produk $\left(\mathrm{X}_{2}\right)$ secara bersama-sama berhubungan dengan variabel keputusan pembelian (Y). Pada nilai derajat hubungan $\mathrm{R}$ diketahui sebesar 0,815 yang artinya berkorelasi tinggi. Kemudian pengujian dengan regresi linier berganda di dapatkan hasil $\mathrm{Y}=7,156+0,262 \mathrm{X}_{1}+0,616 \mathrm{X}_{2}$. Koefisien $\mathrm{b}$ dinamakan koefisien arah regresi dan menyatakan perubahan rata-rata variabel $\mathrm{Y}$ untuk setiap perubahan variabel $\mathrm{X}_{1}$ dan $\mathrm{X}_{2}$ sebesar satu satuan.

Selanjutnya pada Uji $\mathrm{F}$ dalam penelitian ini membandingkan antara $F_{\text {hitung }}$ dan $F_{\text {tabel. }}$. Hasil perhitungan menunjukan bahwa $F_{\text {hitung }}=$ $96,260>\mathrm{F}_{\text {tabel }}=3,09$ dengan nilai signifikan 0,000 , berdasarkan perhitungan tersebut, maka $\mathrm{H}_{03}$ ditolak dan $\mathrm{H}_{\mathrm{a} 3}$ diterima. Sehingga hipotesis yang ketiga berbunyi “Ada pengaruh harga dan kualitas produk dalam keputusan pembelian fried chicken pada Rocket Chicken Bandar Kota Kediri” adalah terbukti kebenarannya. Pengujian terakhir dengan melakukan uji determinasi guna mengetahui adanya pengaruh harga dan kualitas produk terhadap keputusan pembelian fried chicken pada Rocket 
Chicken Bandar Kota Kediri. Hasil yang diperoleh dengan bantuan SPSS 21 nilai determinasi $\left(\mathrm{R}^{2}\right)$ sebesar 0,815 atau $81,5 \%$. Hal ini menunjukkan bahwa harga dan kualitas produk berpengaruh sebesar 81,5\% terhadap keputusan pembelian fried chicken pada Rocket Chicken Bandar Kota Kediri. Sedangkan sisanya sebesar 18,5\% dipengaruhi oleh variabel lain yang tidak diteliti dalam penelitian ini yaitu promosi dan lokasi.

\section{Kesimpulan}

Berdasarkan analisis data dari 100 reponden sebanyak $86 \%$ atau 86 responden menyatakan harga fried chicken di Rocket Chicken dalam kategori murah. Berdasarkan analisis data dari 100 responden sebanyak diperoleh hasil $85 \%$ atau 85 responden menyatakan kualitas produk fried chicken di Rocket Chicken dalam kategori baik. Berdasarkan analisis data dari 100 responden, sebanyak $99 \%$ atau 99 responden menyatakan bahwa keputusan pembelian di Rocket Chicken memilih membeli fried chicken, dalam kategori tinggi.

Variabel harga (X1) dan kualitas produk (X2) secara simultan berpengaruh terhadap keputusan pembelian fried chicken di Rocket Chicken. Nilai uji analisis berganda sebesar 0,815 dengan signifikasi $F$ change 0,000 artinya korelasi sangat kuat. Hal ini dibuktikan dengan nilai $t_{\text {hitung }}=96,260>$ $\mathrm{t}_{\text {tabel }}=3,05$ dengan nilai signifikasi 0,000. Berdasarkan perhitungan tersebut, maka $\mathrm{H}_{03}$ ditolak $\mathrm{H}_{03}$ diterima. Sehingga hipotesis yang ketiga berbunyi "Terdapat pengaruh harga dan kualitas produk terhadap keputusan pembelian fried chicken di Rocket Chicken" adalah terbukti kebenarnya. Sedangkan $\mathrm{R}^{2}$ ditemukan hasil 0,665 artinya besarnya pengaruh variabel harga dan kualitas produk terhadap keputusan pembelian sebesar 66,5\% sedangkan 33,5\% dipengaruhi oleh oleh faktor yang tidak di teliti dalam penelitian ini yaitu lokasi dan promosi. 


\section{Dhea Febriana| Pengaruh Harga dan Kualitas...}

\section{Daftar Pustaka}

Abd Karim Basir, Agus Achmad Suhendra, Sari Wulandari, "Analisis Kebutuhan Produk Keripik Kentang Usaha Kecil Menengah Cumelly Menggunakan Integrasi Food Quality Dan Model Kano", E-Proceeding Of Enggineering : Volume 2, Nomor 3 Issn : 2355-9365,(Desember 2015),7501-7502.

Ghanimata dan Kamal (2012), Analisis Pengaruh Harga, Kualitas Produk, Dan Lokasi Terhadap Keputusan Pembelian, Diponegoro Journal Of Management Vol I No 2.

http://rocketchickenindonesia.com/ diakses pada tanggal 10 september 2018

Kotler Dan Amstrong. Dasar-Dasar Pemasaran, Edisi Ke 9 Jilid 1. Jakarta: PT Indeks Kelompok Gramedia. 2003.

, Prinsip-Prinsip Pemasaran, Terj Imam Nurmawan, Jakarta Erlangga, 2001.

Jakarta:Erlangga,2008.

, Prisip - Prinsip Pemasaran, Edisi Ke-12, , Bauran Pemasaran Edisi 4. Jakarta: PT. Penhalindo.

2010.

Leon, Schiffman dan Kanuk Leslie Lazar, Perilaku Konsumen Edisi 7.

Manampiring, Andrew F. dan Irfan Trang. "Pengaruh Produk, Harga, Promosi dan Tempat terhadap Keputusan Pembelian Mobil di PT. Astral Internasional Tbk Malalayang". Jurnal EMBA. Vol. 4. No. 1. 2016.

Mandasari, Vina (2011), Analisis Kepuasan Konsumen Terhadap Restoran Cepat Saji Melalui Pendekatan Data Mining : Studi Kasus xyz. Jurnal generic vol 6 no 1.

Nisak, Cholifatun, Pengaruh Harga, Keberagaman Model Produk, Kualitas Informasi Dan Kepercayaan Terhadap Keputusan Pembelian Online Pada Toko Tas Online Sabila Store, Jurnal Universitas Diponegoro.

Sujarwendi, Wiratman. Belajar Mudah SPSS Untuk Penelitian Mahasiswa dan Umum. Yogyakarta: Ardana Media. 2008. 
Dhea Febriana| Pengaruh Harga dan Kualitas...

Supangat, Aditya Hangga. Pengaruh Citra Merek, Kualitas Produk, Harga Terhadap Keputusan Pembelian. Jurnal Ilmu dan Riset Manajemen. Vol 6 No 9. 2017.

Walker, Boyd I, Manajemen Pemasaran, Jilid I, Ahli Bahasa Oleh Imam Nurmawan, Jakarta:Erlangga, 1997. 